\title{
IMPLEMENTASI TOLERANSI BERAGAMA DI PONDOK PESANTREN DARUT TAQWA PASURUAN
}

\author{
Erik Sabti Rahmawati dan M. Hatta Satria \\ Fakultas Syariah UIN Maulana Malik Ibrahim Malang \\ erickrahma@yahoo.com
}

\begin{abstract}
Abstrak
This Research was aimed to determine the construct and implementation of the concept of religious tolerance in Darut Taqwa boarding school Pasuruan led by Kyai Sholeh Bahruddin. This study used a qualitative method with a phenomenological approach, whereas the method of data collection used in-depth interviews and documentation. The results of this study showed that: Construct of Kyai Sholeh thought about pluralism and religious tolerance, which is also the foundation for the policy programs at Darut Taqwa boarding school, can be categorized in the inclusive of thought and attitude, which is believe in the existence of truth and salvation of other religions but the highest safety standards of truth remain in their own religion. Kyai Sholeh while promoting the truth of Islam as a religion, but He did not reduce its respect for other religions and not be an impediment to establishing religious tolerance in public life. Kyai Sholeh thought of religious tolerance is also well applied in His policies in managing the boarding school and formal education institutions, which is able to be a reflection of Islam and Islamic boarding school which are inclusive and rahmatan lil alamin.
\end{abstract}

Penelitian ini bertujuan untuk mengetahui konstruk pemikiran dan implementasi toleransi beragama yang dijalankan di Pondok Pesantren Darut Taqwa Ngalah Pasuruaan yang dipimpin oleh Kyai Sholeh Bahruddin. Penelitian ini menggunakan metode kualitatif dengan pendekatan fenomenologi, sedangkan metode pengumpulan data menggunakan dept interview (wawancara mendalam) dan dokumentasi. Hasil penelitian ini menunjukkan bahwa: Konstruk pemikiran Kyai Sholeh tentang pluralisme dan toleransi beragama, yang merupakan landasan kebijakan bagi program-program di Pondok Pesantren Darut Taqwa tersebut, dapat dikategorikan sebagai pemikiran dan sikap inklusif dalam beragama, yaitu pemikiran yang percaya adanya kebenaran dan keselamatan dalam agama lain tapi standar kebenaran dan keselamatan tertinggi tetap berada dalam agamanya sendiri. Kyai Sholeh tetap mengedepankan kebenaran yang ada dalam agama Islam sebagai agama yang dianutnya, namun hal tersebut sama sekali tidak mengurangi penghormatannya terhadap agama lain dan tidak ada sama sekali sikap merendahkan agama lain, serta tidak menjadi ganjalan dalam menjalin toleransi beragama dalam kehidupan bermasyarakat. Pemikiran Kyai Sholeh tentang toleransi beragama juga teraplikasikan dengan baik dalam kebijakannya dalam mengelola pondok pesantren dan lembaga pendidikan formal, yang hal tersebut mampu menjadi cerminan wajah Islam dan pesantren yang inklusif dan rahmatan lil alamin.

Kata Kunci: Pesantren Darut Taqwa, Toleransi Beragama, Kyai Sholeh, Inklusif, multikultural. 
Keyakinan terhadap suatu agama yang mengajarkan tentang kebajikan yang berasal dari satu Tuhan seharusnya membangkitkan kesadaran di kalangan agama-agama akan kebersamaan dalam satu keluarga dan kewajiban untuk berdiri bersama secara persaudaraan. ${ }^{1}$ Namun realitasnya, orang-orang yang beriman di kalangan agama-agama senantiasa saling bertentangan satu-sama lain, bahkan melibatkan pertarungan berdarah, kemudian memandang rendah pengikut-pengikut agama lain sebagai orang-orang bodoh yang tercela dan harus dipertobatkan dengan cara apapun kepada keimanan dan keagamaan yang benar sebagaimana yang dianutnya.

Dalam sejarah, telah terjadi beberapa kekerasan dalam agama; kekejaman penganut Konfusianisme terhadap pengikut Buddhisme di Cina, nasib minoritas Islam di India, pengusiran orang-orang Yahudi pada zaman abad pertengahan Kristen. ${ }^{2}$ Masuknya agama yang dipahami secara sempit dan salah dalam wilayah konflik memiliki kerawanan amat tinggi. Dengan menggunakan label agama, konflik dan kerusuhan makin mudah berkobar dan menyebar. Pada titik ini ada hubungan erat antara pemahaman agama dan kekerasan politik. $^{3}$

Dalam sejarah manusia agama telah menjadi komoditi konflik. Di satu sisi ia telah mengajarkan umat manusia untuk saling mengasihi satu sama lain. Ia telah banyak berjasa menjadikan manusia mengerti arti dan tujuan hidupnya. Namun, di sisi lain, ia juga digunakan alat untuk membasmi komunitas manusia lain, dengan mengatasnamakan agama. Nilai-nilai suci agama menjadi kabur seiring dengan

\footnotetext{
${ }^{1}$ Fredrich Heiler, "Studi Agama Seabagai Persiapan Kerjasama Antaragama" dalam A. Norma Permata, Metodologi Studi Agama, (Yogyakarta : Pustaka Pelajar, 2000), h. 223.

${ }^{2}$ Fredrich Heiler, Studi, h. 224.

${ }^{3}$ Abd A'la, "Merajut Kembali Persatuan Bangsa," Kompas, 3 Agustus 2000.
}

semakin tumpah ruahnya perilaku destruktif manusia. ${ }^{4}$

Persoalan dialog agama muncul dari perkembangan hubungan sosialkemanusiaan yang akhir-akhir ini mulai diperbincangkan, dialog agama sebagai entitas budaya akan merupakan agenda penting dan strategis, lebih-lebih lagi dalam perkembangan kemajemukan masyarakat. ${ }^{5}$

Dialog antar agama di sini tidak dimaksudkan sebagai berdebat argumentasi antara berbagai pemeluk agama, sehingga ada yang menang dan ada yang kalah, dialog antar agama mengutip A. Mukti Ali membiarkan hak setiap orang untuk mengamalkan keyakinannya dan menyampaikannya kepada orang lain. Dialog antar agama adalah pertemuan hati dan pikiran antar pemeluk berbagai agama yang bertujuan mencapai kebenaran dan kerjasama dalam masalah-masalah yang dihadapi bersama. ${ }^{6}$ Dalam hal ini dialog antar agama dapat diarahkan untuk memecahkan masalah-masalah yang dihadapi secara bersama-sama oleh berbagai penganut agama. Inilah yang oleh Muji Sutrisno di istilahkan dengan "dialog antaragama dalam pigura Humanisasi". ? Maksudnya, dialog tersebut berisi pembicaraan mengenai tema-tema sentral problem kemanusiaan universal, seperti kemiskinan, keterbelakangan, kependudukan, lingkungan hidup, hak asasi manusia, kondisi negeri, dan bahkan masalah buruh, yamg kemudian diusahakan solusinya bersama-sama.

Terciptanya dialog dan toleransi antar umat beragama menuntut andil dari semua pihak, terutama tokoh-tokoh masyarakat dan tokoh-tokoh agama setempat, karena untuk masyarakat menengah kebawah contoh perilaku dan

\footnotetext{
${ }^{4}$ Andito (ed.), Atas Nama Agama; Wacana Agama Dalam Dialog Bebas Konflik, (Bandung: pustaka Hidayah, 1998), h. 10.

${ }^{5}$ Munir Mulkhan, "Agama Dalam Dialog Budaya", dalam Andito (ed.), Atas Nama Agama, h. 281-283.

${ }^{6}$ Arief Subhan, Ilmu, h.

${ }^{7}$ Baca Muji Sutrisno, "Dialog Agama Dalam Pigura Humanisasi” dalam Andito (ed.), Atas Nama Agama, h. 333-337.
} 
Erik Sabti Rahmawati dan M. Hatta Satria, Implementasi Toleransi Beragama ... | 97

pernyataan atau himbauan dari figur-figur tersebut sangat berpengaruh dalam kehidupan mereka. Salah satu figur yang sangat berpengaruh dalam masyarakat Islam adalah seorang kyai, figur kyai sangat signifikan dalam mensosialisasikan pentingnya dialog dan toleransi antar umat beragama. Hal inilah yang telah dilakukan oleh KH. Sholeh Bahruddin Kalam Pengasuh Pondok Pesantren Ngalah Sengonagung Purwosari Pasuruan Jawa Timur. Selain disegani oleh masyarakat Muslim, beliau juga disegani oleh ummat agama lain karena beliau dikenal sebagai seorang kyai yang sangat toleran, yang sikap dan pandangannya terhadap komunitas agama lain sangat apresiatif. Seperti halnya ketika para tokoh dan pemuka agama umat Kristiani yang melakukan kunjungan serta diskusi tentang pluralisme di Pondok Pesantren Ngalah Pasuruan. ${ }^{8}$ Oleh karenanya, tentu sangat diperlukan sosialisasinya secara akurat agar dapat dijadikan cermin atau panutan bagi tokohtokoh agama di daerah-daerah lain, sehingga kehidupan berbangsa dan bernegara tidak akan terganggu oleh berbagai perbedaan dan dialog agama serta toleransi yang sejati akan senantiasa terjalin dalam masyarakat.

Berdasarkan uraian diatas, maka dapat dinyatakan bahwa tujuan penelitian ini adalah 1) Untuk mengetahui pemahaman terhadap toleransi beragama di Pondok Pesantren Darut Taqwa Ngalah Pasuruan. 2) Untuk mengetahui implementasi toleransi beragama dalam pembelajaran dan kegiatankegiatan yang dilaksanakan Pondok Pesantren Ngalah Pasuruan.

\section{Metode Penelitian}

Metode penelitian merupakan salah satu faktor yang paling penting dalam memberikan arahan kemana lajunya atau arahnya sebuah penelitian. Adapun jenis penelitian yang digunakan dalam penelitian ini yaitu penelitian empiris. Penelitian

\footnotetext{
${ }^{8}$ Darut Taqwa, "100 Pendeta Kunjungi Ponpes Ngalah", http://blog.daruttaqwa.or.id/2010/03/apajadinya-kalau-100-pendeta.html, diakses tanggal 10 Mei 2011.
}

empiris digunakan untuk menganalisis hukum yang dilihat sebagai prilaku masyarakat yang berpola dalam kehidupan masyarakat yang selalu berinteraksi dan berhubungan dalam aspek kemasyarakatan. ${ }^{9}$

Penelitian ini bertujuan untuk menggambarkan semua realita secara rinci dan tuntas tentang fenomena yang terjadi di Ponpes Darut Taqwa Ngalah Pasuruan terkait dengan kehidupan beragama. Penelitian ini menggunakan metode kualitatif yang juga berdasar pada pendekatan fenomenologi. Dalam pendekatan fenomenologi, Obyek penelitiannya ialah fenomin, yang menurut Husserl, adalah fakta atau relasi yang dapat diserap dalam observasi empiris; dan harus dialami menurut kehadirannya. Tapi fenomin dapat juga hanya merupakan pandangan rohani yang dapat diserap melaui wawancara mendalam (deep interview). ${ }^{10}$ Fenomin yang menjadi obyek penelitian adalah pemahaman dan pengalaman aplikatif pengasuh pondok pesantren Darut Taqwa Ngalah Pasuruan terkait dengan pemikiran tentang toleransi antar umat beragama dan kebijakan-kebijakan yang telah dilakukan berdasarkan atas pemikirannya tersebut.

Dalam usaha pengumpulan data yang diperlukan dalam penelitian ini digunakan dua metode yaitu, wawancara mendalam (dept interview) dan dokumentasi. Metode wawancara digunakan untuk menggali pemahaman dan konsep toleransi agama yang dikembangkan di pondok pesantren dengan melakukan wawancara kepada pengasuh utama PP. Darut Taqwa yaitu KH. Sholeh Badruddin Kalam. Adapun metode dokumentasi digunakan untuk mengetahui kebijakankebijakan KH. Sholeh yang terkait dengan konsep toleransi agama dalam kegiatan dan program pesantren, namun untuk melengkapi dua metode diatas juga dilakukan kegiatan pengamatan (observation), metode ini berwujud

\footnotetext{
${ }^{9}$ Bambang Sunggono, Metodologi Penelitian Hukum (Jakarta: PT Raja Grafindo Persada, 2003), h. 43.

${ }^{10}$ Anton Bakker, Metode, h. 111.
} 
98| de Jure, Jurnal Syariah dan Hukum, Volume 6 Nomor 1, Juni 2014, hlm. 95-106

pengamatan dan pencatatan secara sistematis terhadap fenomena-fenomena yang diselidiki. ${ }^{11}$

\section{Hasil dan Pembahasan}

\section{Pluralisme Agama di Indonesia}

Menurut Alwi Shihab, pluralisme tidak semata menunjuk pada kenyataan adanya kemajemukan tetapi sekaligus menuntut keterlibatan aktif terhadap kenyataan kemajemukan tersebut. Seseorang dapat dikatakan menyandang sikap pluralis jika dapat berinteraksi positif dengan lingkungan kemajemukan tersebut. Dengan kata lain, pluralisme dalam konteks agama adalah bahwa tiap pemeluk agama dituntut bukan saja mengakui keberadaan dan hak agama lain, tapi juga terlibat dalam usaha memahami perbedaan dan persamaan guna tercapainya kerukunan dalam kebhinnekaan.

Lebih jauh, Nurcholish berpendapat bahwa pada dasarnya semua agama yang ada menganut prinsip sama, yaitu keharusan manusia untuk berserah diri (aslama, islam) pada Tuhan Yang Maha Esa. Agama-agama tersebut, baik karena dinamika internalnya sendiri atau karena persinggungan dengan yang lain, akan secara berangsur-angsur menemukan kebenarannya sendiri sehingga semuanya akan bertumpu dalam suatu titik pertemuan yang dalam istilah al-Qur'an disebut kalamat sawa'. ${ }^{2}$ Dari perspektif positif, dapat dikatakan bahwa kaum muslim klasik telah berhasil sepenuhnya menginternalisasi konsepsi tentang manusia yang positif dan optimistik, konsepsi yang kemudian menjadikan mereka komunitas yang amat kosmopolit dan universalis, sehingga bersedia belajar dan menerima segala yang bernilai dari pengalaman komunitas lain yang berbeda agama.

Dalam peristiwa Fath al-Makkah, Nabi tidak mengambil tindakan balas dendam pada mereka yang pernah mengusirnya dari tanah kelahirannya. Sebaliknya, beliau justru memberi kebebasan penuh kepada mereka. Peristiwa

\footnotetext{
${ }^{11}$ Sutrisno Hadi, Metodologi Research, (Jld. II;

Yogyakarta: Andi Ofset, 1989), h. 136.

${ }^{12}$ Siti Nadroh, Wacana.
}

ini memberi contoh konkrit sekaligus contoh pemahaman dan penghayatan pluralitas agama yang riil dihadapan umatnya. Nabi tidak menuntut truth claim tapi memilih sikap agree in disagreement. Nabi tidak memaksakan agamanya untuk diterima orang lain tanpa kesadaran hatinya. Ini menunjukkan bahwa nabi sangat mengakui eksistensi dan keberadaan agama-agama selain Islam. Dalam Islam, etika keberagamaan, khususnya terkait dengan hubungan antar umat beragama adalah terbuka dan dialogis. ${ }^{13}$

Tidak berbeda dengan pengertian dan gagasan pluralisme di atas, Esack mengartikan pluralisme sebagai pengakuan dan penerimaan tentang adanya keberbedaan dan keragaman, baik di antara sesama agama maupun pada penganut agama lain, yang lebih dari sekedar toleransi. Dalam konteks agama, pluralisme berarti penerimaan cara menanggapi dorongan, yang terlihat atau tidak, yang ada dalam diri setiap manusia ke arah Yang Transenden. ${ }^{14}$ Artinya, pluralisme agama adalah penghargaan, pengakuan dan penerimaan atas sikap-sikap serta perilaku penganut agama lain (yang jelas berbeda dengan kita) dalam upaya mereka untuk mendekatkan dirinya kepada Tuhan.

Menurut Esack, al-Qur'an sesungguhnya mengajarkan sikap-sikap pluralis dan justru mengecam sikap-sikap eksklusifisme. Kecaman-kecaman ini, antara lain, tampak pada celaan yang diberikan alQur'an pada klaim sebagian ahli kitab bahwa kehidupan hanya untuk mereka dan "tidak diperuntukkan bagi orang lain" (QS. al-Baqarah, 94; 111).

Berbeda dengan pemikiran diatas, tidak sedikit tokoh-tokoh agama yang berpandangan subyektif dan ekslusif dalam menyikapi pluralitas agama, sebagaimana penafsiran klasik yang dilakukan al-Razi, Zamakhsyari dan Thabari berkenaan dengan ayat-ayat antar-iman. Menurut Esack, para mufasir ini telah bersikap sangat subyektif

\footnotetext{
${ }^{13}$ Amin Abdullah, Studi Agama, h. 74.

${ }^{14}$ Esack, Qur'an, h. xii.
} 
Erik Sabti Rahmawati dan M. Hatta Satria, Implementasi Toleransi Beragama ...| 99

atau bahkan terlalu mengada-ada dalam memahami teks yang telah jelas maknanya. Ketika menafsirkan ayat-ayat yang jelasjelas mengakui akan adanya keanekaragaman agama (QS, al-Maidah, 48; al-Baqarah, 148; al-Hajj, 67) atau penerimaan dan hak keselamatan bagi agama lain (QS. al-Baqarah, 62; al-Maidah, 69), mereka justru berusaha menghindari makna eksplisit teks dengan menggunakan atau bahkan menciptakan berbagai perangkat tafsir untuk memperoleh penafsiran yang sesuai dengan sikap mereka, eksklusif. ${ }^{15}$

Penelitian ini didasarkan atas teori pokok tentang sikap keberagamaan manusia. Dalam masalah ini, paling tidak ada tiga tipe sikap yang ditunjukkan umat: ekskusif, inklusif, dan pluralis. ${ }^{16}$ Sikap eksklusif adalah pandangan yang mengklaim bahwa kebenaran dan keselamatan hanya ada dalam agamanya sendiri. ${ }^{17}$ Sikap inklusif adalah pandangan yang percaya adanya kebenaran dan keselamatan dalam agama lain tapi standar kebenaran dan keselamatan tetap berada dalam agamanya sendiri. Sedangkan sikap pluralis adalah paradigma pemikiran yang berpendapat bahwa setiap agama mempunyai kebenaran dan jalan keselamatan sendiri-sendiri sehingga tidak ada yang berhak mengklaim hanya agamanya yang benar. ${ }^{18}$

\section{Kondisi Objektif Pondok Pesantren Darut Taqwa Ngalah Pasuruan}

Pendiri dan Pengasuh Pondok Pesantren Darut Taqwa Ngalah Pasuruan adalah KH. Moh. Sholeh Bahruddin Kalam yang lebih akrab di panggil Romo Kyai Sholeh oleh santri-santrinya. Beliau dilahirkan di desa Carat Gempol Pasuruan pada hari sabtu 25 Sya'ban $1372 \mathrm{H}$ yang

\footnotetext{
${ }^{15}$ Esack, Qur'an, h. 162-163

16 Alwi Shihab, Islam Inklusif, h. 84-45, Budhy Munawar Rahman, Islam Pluralis, h. 44-49.

${ }^{17}$ John Lyden (ed), Enduring Issues In Religion, (San Diego: Greenhaven Press Inc, 1995), h. 63.

18 John Lyden (ed), Enduring Issues In Religion, h. 74.
}

bertepatan pada tanggal 09 Mei $1953 \mathrm{M}$ dan merupakan putra pertama dari sebelas bersaudara dari pasangan KH. M. Bahruddin Kalam dan Nyai Shofurotun. ${ }^{19}$

Romo Kyai melanjutkan pendidikan agama di berbagai pesantren. Tercatat ada beberapa Kyai pesantren yang menjadi guru beliau dalam memperdalam ilmu agama, termasuk diantaranya yaitu KH. Qusyairi: Mojosari Mojokerto Jawa Timur, KH. Bahri: Sawahan Mojosari Mojokerto Jawa Timur, KH. Jamal: Batho'an Mojo Kediri Jawa Timur, KH. Musta'in: Peterongan Jombang Jawa Timur, KH. Iskandar: Kandangan Ngoro Jombang Jawa Timur, KH. Muslikh: Meranggen Semarang Jawa Tengah, KH. Munawir: Tegal Arum Kertosono Nganjuk Jawa Timur.

Setelah selesai mendalami pendidikan agama di berbagai pondok pesantren, pada usia 22 tahun, tepatnya pada tahun 1975, beliau meminang Nyai Hj. Siti Sa'adah dari Trenggalek untuk dijadikannya sebagai pendamping hidup, yang mana secara silsilah atau garis keturunan beliau dengan Nyai Siti Sa'adah masih ada satuan garis keturunan. Dari pernikahan tersebut beliau dikaruniai sepuluh anak, yaitu Siti Muthoharoh, Atik Hidayatin, Ahmad Syaikhu, Siti Faiqoh, Luluk Nadliroh, Siti Khurrotin, M. Faisal (A.lm), M. Busthomi (Alm), Siti Hajar dan Siti Nuronia. ${ }^{20}$

Sedangkan Pondok Pesantren Ngalah sendiri didirikan oleh KH Moh. Sholeh Bahruddin Kalam pada bulan 30 Agustus 1985 Masehi atau bertepatan dengan Jum'at Pahing bulan 14 Dzulhijjah 1405 Hijriyah. ${ }^{21}$

\section{Kontruksi Pemikiran dan Konsep Toleransi Beragama Pondok Pesantren Darut Taqwa Ngalah Pasuruan.}

\footnotetext{
${ }^{19}$ KH. Moh. Sholeh Bahruddin, Wawancara, (Sengonagung, 19 Agustus 2011).

${ }^{20}$ Pondok Pesantren Ngalah, Biografi. h. 1

${ }^{21}$ Pondok Pesantren Ngalah, "Sejarah Singkat Ponpes Ngalah", http://pondokngalah.net/pesantren/profil/sejarah.html , diakses pada tanggal 20 Agustus 2011.
} 
100 | de Jure, Jurnal Syariah dan Hukum, Volume 6 Nomor 1, Juni 2014, hlm. 95-106

Kontruksi pemikiran yang dibangun di Pondok Pesantren Darut Taqwa Ngalah Pasuruan terkait dengan konsep toleransi beragama tentu tidak lepas dari peran utama Kyai Sholeh, yang hal tersebut di latarbelakangi tingkat kemajemukan yang sangat tinggi di Negara Indonesia ini. Oleh karenanya untuk menumbuhkan kesadaran sikap yang merupakan salah satu ikhtiar, agar para generasi bangsa Indonesia mampu menjadi gawang kerukunan dan perdamaian bangsa Indonesia. Berikut penyampaian beliau:

"Dengan ini yayasan Darut-Taqwa memberanikan diri untuk menjadi solusi bagi kerukunan antar umat beragama, dan hal ini merupakan sumbangsih (baca: sumbangan) terhadap bangsa dan Negara." ${ }^{22} \mathrm{Hal}$ ini ditunjang dengan beberapa rancangan pemikiran Kyai Sholeh yaitu tentang Islam dan Pancasila, Islam dan Bhinneka Tunggal Ika, dan Pancasila sebagai Asas Yayasan Darut-Taqwa.

Islam dan Pancasila, Dalam pancasila itu sendiri mengandung nilai-nilai universal dengan prinsip "Bhinneka Tunggal Ika"nya, hal itu mempuyai proses yang sangat panjang dalam pembentukannya dan pada akhirnya disepakati sebagai konsensus nasionall untuk menjadi dasar negara NKRI dan menjadi payung kehidupan bersama dalam berbagai perbedaan.

$$
\text { Kyai Sholeh menguatkan }
$$

pendapatnya dengan cara melihat secara jernih bahwa Pancasila itu adalah payung kebersamaan. Hal ini dapat dibuktikan dengan melihat kesesuaian sila-sila atau butir-butir yang terkandung dalam Pancasila dengan ayat-ayat Tuhan yang termaktub didalam kitab sucinya yakni al-Qur'an alKarim, berikut ini penjabarannya: ${ }^{23}$ (1) Sila pertama: Ketuhanan Yang Maha Esa, mengandung ajaran ketauhidan dalam pengertian keimanan kepada Tuhan Yang Maha Esa. Hal ini sebagaimana tercermin dalam firman Allah SWT surat al-Nahl ayat

\footnotetext{
${ }^{22}$ KH. Moh. Sholeh Bahruddin, Wawancara, (Sengonagung, 19 Agustus 2011).

${ }^{23}$ Santri Muallimin Muallimat Ponpes Ngalah, Buku, h. 2-6.
}

22; al-Baqarah ayat 163; al-Ankabut ayat 46. (2) Sila kedua: Kemanusiaan Yang Adil dan Beradab, mencerminkan nilai kemanusiaan yang menjunjung tinggi sikap adil dan beradab. Sebagaimana dalam ayat suci al-Qur'an surat al-Nahl ayat 90. (3) Sila ketiga: Persatuan Indonesia, menggambarkan sebuah kehidupan yang rukun, damai, saling berdampingan dalam bingkai keanekaragaman bengsanya dengan dilandasi persatuan dan kebersamaan. Sebagaimana tercantum dalam kitab suci alQur'an surat al-Imron ayat 103. (4) Sila keempat: Kerakyatan Yang Dipimpin Oleh Hikmat Kebijaksanaan Dalam Permusyawaratan Perwakilan, memberi petunjuk dalam pelaksanaan kepemimpinan serta dalam mengambil sebuah keputusan harus secara bijak dengan tetap berdasarkan musyawarah. Sebagaimana dalam kitab suci al-Qur'an surat Shaad ayat 20. (5) Sila kelima: Keadilan Sosial Bagi Seluruh Rakyat Indonesia, menggambarkan dan mencita-citakan terwujudnya kehidupan yang adil, makmur, bagi seluruh rakyatnya yang beranekaragam. Sebagaimana tercantum dalam kitab suci al-Qur'an surat al-Ma'idah ayat 8 .

Islam dan Bhinneka Tunggal Ika, Bhinneka Tunggal Ika yang berartikan berbeda-beda tetapi tetap satu jua. Bhinneka Tunggal Ika memiliki makna mendalam walaupun di Indonesia sebagai Negara yang multikultural, dimana terdapat banyak suku, agama, ras, kesenian, adat, bahasa dan lain sebagainya tetapi tetap satu kesatuan yakni sebangsa dan setanah air. Apabila terjadi perpecahan antar umat beragama, maka akan terjadilah perang besar di muka bumi ini, seperti halnya apa yang disampaikan oleh Kyai Sholeh:

"Kalo perang antar partai paling Cuma puluh ribuan yang mati, perang Negara hanya puluh juta sampai ratusan juta, akan tetapi jika terjadi perang antar agama yang akan terjadi beribu-ribu-riburibu-ribu-ribu juta manusia yang menjadi korban."24

\footnotetext{
${ }^{24}$ KH. Moh. Sholeh Bahruddin, Wawancara.
} 
Erik Sabti Rahmawati dan M. Hatta Satria, Implementasi Toleransi Beragama ...| 101

Pancasila sebagai Asas Yayasan Darut Taqwa, Pada setiap moment wisuda (pelepasan) santri atau murid baik pada lembaga pendidikan formal (MI, MTS, MASMK, SMA dan Perguruan Tinggi) dan non formal (Madrasah diniah; Haflah Akhirussanah), kyai Sholeh selalu mewariskan kepada wisudawan agar tetap berpegang teguh kepada Pancasila sampai akhir hayat nanti. Karena Pancasila merupakan warisan leluhur kita, yakni para pendiri bangsa, dan telah ditetapkan sebagai dasar Negara Kesatuan Republik Indonesia untuk dijadikan pedoman bagi setiap warga negaranya dalam menjalankan kehidupan berbangsa dan bernegara di bumi pertiwi ini. Oleh karenanya Darut Taqwa sebagai Yayasan Pendidikan yang terletak di Dusun Pandean Desa Sengonagung Purwosari Pasuruan akan selalu berwawasan Rahmatan Lil 'Alamin dan berasaskan Pancasila untuk selama-lamanya. ${ }^{25}$

Sebagai bentuk komitmen dan sekaligus untuk mempertahankan dan menjaga kokohnya NKRI, KH. Moh. Sholeh Bahruddin mengeluarkan ma'lumat terkait dengan adanya upaya dari golongan atau kelompok yang berkeinginan untuk merubah dasar Negara Indonesia, Beliau menyatakan dengan tegas mengambil sikap untuk tidak setuju kalau Negara Indonesia ini dijadikan Negara yang berbentuk Negara Islam.

Konstruksi pemahaman Kyai Sholeh tentang toleransi beragama tidak lepas dengan Pancasila sebagai dasar NKRI, beliaupun tidak ingin bangsa ini terpetakpetakan dan atau tersekat-sekatkan oleh suku, ras, maupun agama. Hal ini tidak lain untuk mewujudkan satu kesatuan bangsa Indonesia. Beliau memperoleh pemikiran yang sedemikian rupa tidak lain karena dawuh (pesan) orang tuanya yang selalu mengingatkannya, bahwa "ndek endi-endi iku dulurmu kabeh le, gak ndek pasar, ndek langgar, ndek dalan-dalan iku kabeh dulurmu" (dimana-mana itu saudaramu nak, baik di pasar, di langgar, dan di jalan-jalan

\footnotetext{
${ }^{25}$ Santri Muallimin Muallimat Ponpes Ngalah, Buku, h. 11 .
}

pun semuanya saudaramu). Sejak dari kecilpun beliau juga diberi contoh untuk tidak membeda-bedakan dalam bergaul dengan masyarakat muslim ataupun non muslim. Karena ditengah-tengah perbedaan diantara sesama manusia, beliau mempunyai prinsip-prinsip yaitu kasih sayang antar sesama, saling mengenal, saling menghargai, saling tolong menolong.

Prinsip diatas memberikan gambaran bahwa dalam menggalang kerukunan umat beragama diperlukan sikap arif dan bijaksana ketika memahami agama orang lain. Usaha ini diperlukan sikap rendah hati yang sangat dalam dan keterbukaan dalam menanggapi segala hal yang diterima, meskipun keyakinan mereka berbeda dengan apa yang kita yakini. Sebaliknya dalam Islam melarang bertindak merendahkan sesama manusia, bermusuhmusuhan, apalagi saling membinasakan. ${ }^{26}$ Hal ini sesuai dengan firman Allah dalam surat al-Ma'idah, ayat 32 .

\section{Implementasi Toleransi Beragama di Pondok Pesantren Darut Taqwa Ngalah Pasuruan.}

Pada dasarnya agama hadir dalam lingkungan peradaban manusia sebagai petunjuk dan pembawa ketentraman bagi umatnya. Ajaran agama apapun mengajarkan kedamaian, bukan kekerasan. Karena ajaran agama tidak hanya mengajarkan interaksi antara manusia dengan Tuhannya saja, melainkan juga mengajarkan berinteraksi antara manusia dengan manusia dan manusia dengan alam.

Visi kehadiran agama yang mengajarkan perdamaian seringkali ternodai oleh bentuk tawuran (budaya kekerasan) yang semakin marak terjadi di tengahtengah kehidupan masyarakat kita. Seringkali ajaran agama dijadikan legitimasi (dasar pembenar) atas tindakan kekerasan, seolah-olah mereka yang melakukan kekerasan benar akan tindakannya. Boleh jadi, gejala ini merupakan salah satu

\footnotetext{
${ }^{26}$ Ahmad Najib Burhani, Islam Dinamis: menggugat peran agama membongkar doktrin yang membantu, (Jakarta:Kompas Media Nusantara, 2001), h. 5.
} 
perwujudan dari minimnya komunikasi antara umat beragama yang satu dengan yang lain, sehingga menimbulkan kecurigaan diantara mereka. sebagaimana pernyataan KH. Sholeh:

"Pada saat umat muslim merusak gerejagereja. Contohnya pada waktu FPI (Front Pembela Islam) dan JI (Jama'ah Islamiyah) merusak gereja-gereja, seandainya dibiarkan terus-menerus akan mengakibatkan perang antar agama.

Dari sini dapat dipahami bahwa konsep dialog antar agama menjadi suatu kebutuhan untuk menghindari segala bentuk tindak kekerasan. Karena konsep tersebut mengupayakan terjadinya kerukunan antar umat beragama dengan jalan menjalin komunikasi lintas agama secara intensif. Dengan komunikasi secara terus-menerus diharapkan dapat mengurangi tindak kekerasan, terutama yang bersumber dari ajaran agama. Untuk itulah Yayasan Darut Taqwa bekerja sama dengan Ponpes Ngalah Sengonagung, serta Universitas Yudharta Pasuruan mengaplikasikan pemahamannya dalam beberapa kegiatan dan pembentukan beberapa lembaga, yaitu:

\section{Kegiatan seminar nasional antar umat beragama dan silaturrahmi tokoh lintas agama.}

Kegiatan lintas agama dan budaya, seperti halnya seminar nasional membangun kerukunan umat beragama, yang dihadiri berbagai tokoh lintas agama sering diselenggarakan dan diadakan oleh Yayasan Darut Taqwa, begitu juga dengan silaturahmi keagamaan, dimana Yayasan Darut Taqwa dan lembaganya sering melakukan kunjungan-kunjungan ke berbagai gereja, vihara dan tempat-tempat ibadah yang lainnya, hal ini tidak lain adalah sebagai bentuk komitmen bahwa Yayasan Darut Taqwa yang ingin membangun kerukunan antar umat beragama dengan tujuan supaya tidak terjadi perang saudara di bumi tecinta ini. Begitupun sebaliknya, pada tanggal 17 Maret 2010 sebanyak 100 (seratus) pendeta GKI (Gereja Kristen Indonesia) telah mengadakan kunjungan ke
Ponpes Ngalah dan berdiskusi masalah Plural dan Multikultural yang bertajuk "Memperkokoh Plural dan Multikultural Menuju Peradaban Dunia Yang Damai dan Bermartabat".

Terakhir kali proyek seminar yang diselenggarakan pada tanggal 22 Mei 2010. Seminar Kebangsaan yang bertema "Memperkokoh Nilai-nilai Pluralisme dan Multikultural Menuju Peradaban Dunia yang Damai dan Bermartabat" tersebut diselenggarakan dalam rangka memperingati hari Kebangkitan Nasional ke-102. Adapun narasumber yang telah menyempatkan waktunya untuk mengisi acara tersebut yakni Prof. Dr. Ir. H. M. Nuh (Menteri Pendidikan Nasional), Nyai Hj. Shinta Nuriyah (Istri Gus Dur), Mr. Volker Martin Dally, M.Div (IPTH Balai Wiyata Malang dari Jerman), Ketua Umum PB NU 2010-2015. ${ }^{27}$

Dari kegiatan seminar nasional kerukunan antar umat beragama tersebut telah dihasilkan sebuah buku yang berjudul "SERUMPUN BAMBU (Jalan Menuju Kerukunan Sejati)". ${ }^{28}$ Dengan adanya buku tersebut bisa menjembatani komunikasi antar agama agar memahami perbedaan sebagai upaya dalam menciptakan kehidupan harmonis antar umat beragama. Berikut penyampaian Kyai Sholeh terkait dengan seminar dengan tujuan demi kerukunan antar umat beragama tersebut:

"Demi bangsa dan Negara biar aman tentram dan damai, Darut-Taqwa memberanikan diri mengadakan seminar untuk merukunkan semua umat. Jadi semua delegasi semua agama saya undang untuk menghadiri seminar. ${ }^{29}$

\section{Pembangunan fasilitas pendidikan formal} Dengan itu KH. Moh. Sholeh Bahruddin mempunyai cita-cita besar, serta

\footnotetext{
${ }^{27}$ Seminar Kebangsaan, Jadwal Acara, http://seminar2010.daruttaqwa.or.id/2010/03/jadualacara.html, diakses pada tanggal 14 Oktober 2011.

${ }^{28}$ Seminar Kebangsaan, Term Of Reference Penyusunan dan Penerbitan Buku, http://seminar2010.daruttaqwa.or.id/search/label/TO $\mathrm{R}$, diakses pada tanggal 14 Oktober 2011.

${ }^{29}$ KH. Moh. Sholeh Bahruddin, Wawancara.
} 
Erik Sabti Rahmawati dan M. Hatta Satria, Implementasi Toleransi Beragama ...| 103

keinginan dan kemauan yang kuat untuk memberikan fasilitas-fasilitas bagi umat non muslim yang ingin menempuh pendidikan formal tanpa membedakan statusnya antara muslim dan nonmuslim.

Dalam pembangunan lembaga pendidikan formal memiliki proses yang cukup panjang, tidak langsung serentak mendirikan lembaga tersebut secara bersamaan, akan tetapi bertahap. Diawali pada tahun 1987, Yayasan Ponpes Darut Taqwa mendirikan lembaga pendidikan MTS. Darut Taqwa 02 yang berlokasi di Desa Sengonagung sebagai bentuk kepedulian KH. Sholeh Bahruddin terhadap pendidikan, Selanjutnya mendirikan lembaga pendidikan MA Darut Taqwa pada tahun 1989, mendirikan MI Darut Taqwa pada tahun 1990, pada tahun 1995 mendirikan kelas jauh Raudlotul Atfal (RA) setingkat dengan TK. Selanjutnya Kyai Sholeh untuk tetap pada komitmennya dalam meningkatkan pendidikan bangsa mendirikan STAIS (Sekolah Tinggi Agama Islam Sengonagung) dengan 2 jurusan yakni Pendidikan Agama Islam (PAI) dan Pendidikan Bahasa Arab (PBA) dengan menunjuk Rojil Ghufron, SH sebagai Ketua STAIS pertama. Pada tahun 1999 mendirikan SMA Darut Taqwa, dan pada tahun 2005 STAIS berubah menjadi Universitas Yudharta Pasuruan, dengan 5 (lima) Fakultas (Fakultas Teknik, Pertanian, Sosial \& Politik, Psikologi, FAI), Pendirian SMK Darut Taqwa.

\section{Pembangunan Universitas Yudharta Pasuruan sebagai The Multicultural University.}

Berdirinya Universitas Yudharta Pasuruan (UYP), juga merupakan wujud kepedulian anak bangsa yang ingin ikut berpartisipasi mencerdaskan kehidupan bangsanya. hal ini berawal dari keinginan Kyai Sholeh untuk melanjutkan komitmen dan cita-citanya dalam rangkan turut mencerdaskan kehidupan bangsa, yaitu dengan mendirikan kelas jauh STAIP (Sekolah Tinggi Agama Islam Pasuruan) jurusan Pendidikan Agama Islam untuk memberikan bekal kepada santrinya agar berwawasan lebih tinggi pada tahun 1994, kemudian pada tahun 1996 Beliau mendirikan STAIS (Sekolah Tinggi Agama Islam Sengonagung) dengan 2 jurusan yakni Pendidikan Agama Islam (PAI) dan Pendidikan Bahasa Arab (PBA) dengan menunjuk Rojil Ghufron, SH sebagai Ketua STAIS pertama. ${ }^{30}$

Kehadiran sosok KH. Abdurrahman Wahid (Gus Dur) selaku Ketua Umum PBNU pada tanggal 20 Oktober 2006 ke Ponpes Ngalah dalam rangka kuliah tamu mahasiswa STAIS sangat berkesan dan berharap besar kepada Kyai Sholeh agar menjadikan Pondok Pesantren Ngalah sebagai pusat kajian NU dan pusat pengkaderan kader NU dimasa yang akan datang, menjadikan kemantapan hati Kyai Sholeh untuk mempersiapkan berdirinya Universitas di Kabupaten Pasuruan. Alhamdulillah, tepatnya tanggal 1 Agustus 2002 berdasarkan SK Mendiknas No. 146/D/O/2002 berdirilah Universitas Yudharta di Kabupaten Pasuruan yang berada dilingkungan Ponpes Ngalah dibawah naungan Yayasan Darut Taqwa dan yang diberi amanah sebagai Rektor Universitas Yudharta yang pertama adalah Dr. H. Muhammad Sochib, M.Pd. Adapaun ijin penyelenggaraan Universitas Yudharta telah diperbarui dengan diterimanya SK Dirjen Pendidikan Tinggi No. 919 929/D/O/2005. ${ }^{31}$ STAIS merubah menjadi Universitas Yudharta Pasuruan, dengan 5 (lima) Fakultas (Fakultas Teknik, Pertanian, Sosial \& Politik, Psikologi, FAI).

Universitas Yudharta Pasuruan mengsingkronisasikan The Multicultural University dengan semboyan dalam lambang Negara Republik Indonesia yaitu "Bhinneka Tunggal Ika". Yang mana intinya menggambarkan kehidupan masyarakat Indonesia yang plural, dilandasi dengan

\footnotetext{
${ }^{30}$ Darut Taqwa, Profil.

${ }^{31}$ Seminar Kebangsaan, Profil Penyelenggara

Universitas Yudharta Pasuruan,

http://seminar2010.daruttaqwa.or.id/2010/03/profilpenyelenggara-universitas.html, tanggal 14 Oktober 2011
} 
berbagai perbedaan, baik secara horizontal maupun vertikal. Perbedaan horizontal meliputi suku bangsa, bahasa, adat istiadat dan agama. Sementara perbedaan yang bersifat vertikal yakni menyangkut perbedaan-perbedaan lapisan atas dan bawah, yang menyangkut bidang politik, social, ekonomi, maupun budaya. Walaupun terdapat berbagai perbedaan baik secara horizontal ataupun vertikal bangsa kita masih tetap satu-kesatuan yaitu satu bangsa dan satu tanah air. Dipersatukan dengan bendera, lagu kebangsaan, mata uang, bahasa dan lain sebagainya. $^{32}$

Bahkan perencanaan terakhir Kyai Sholeh ingin mendirikan sebuah wisma (tempat tinggal) bagi murid ataupun mahasiswa non muslim yang sedang mengenyam pendidikan pada lembaga yang dinaungi Yayasan Darut Taqwa tersebut. Karena sampai saat ini, baik murid, mahasiswa ataupun staf pengajar (dosen) masih bertempat tinggal di luar area Ponpes, walaupun masih dalam pengawasan Ponpes. Planning daripada Kyai Sholeh hanya tidak ingin ada perbedaan terkait dengan fasilitasfasilitas yang diperoleh antara muslim dengan non muslim. Berikut penyampaian Bendahara Ponpes Ngalah:

"Romo Kyai mempunyai rencana, bagi mahasiswa yang non muslim akan dibuatkan wisma. Tujuannya tidak lain ingin memberi kenyamanan bagi mahasiswa yang menempuh pendidikan di Universitas Yudharta. "33

Totalitas Pesantren Darut Taqwa dalam komitmennya untuk membangun kerukunan umat beragama tidak tanggungtangung, hal tersebut terlihat jelas dari maklumat Kyai Sholeh yang terpampang jelas di depan Kantor Pesantren (lihat lampiran 2), yang juga teraplikasi dalam visi yang dikembangkan oleh Universitas Yudharta Pasuruan sebagai The Multicultural University. UYP sebagai salah satu institusi Perguruan Tinggi, ingin menjadikan kampusnya sebagai kampus

\footnotetext{
${ }^{32}$ Abu Amar Bustomi, Serumpun, h. xiii

${ }^{33}$ Achmad Yusuf, Wawancara, (Sengonagung, 19 Agustus 2011).
}

rakyat, yang mengantarkan mahasiswanya menjadi manusia kaffah; manusia relegius yang memiliki kualitas intelektual maupun kesalehan social, hidup dalam suasana toleran dan berdampingan (egaliter).

\section{Kesimpulan}

Berdasarkan data hasil penelitian berikut pembahasan analisis data dalam penelitian ini dapat disimpulkan bahwa Konstruk pemikiran Kyai Sholeh tentang pluralisme dan toleransi beragama, yang merupakan landasan kebijakan bagi program-program di Pondok Pesantren Darut Taqwa tersebut, apabila dikaitkan dengan tiga tipologi keberagaman yang menjadi kerangka teori dalam penelitian ini dapat dikategorikan kepada sikap inklusif, yaitu pandangan yang percaya adanya kebenaran dan keselamatan dalam agama lain tapi standar kebenaran dan keselamatan tertinggi tetap berada dalam agamanya sendiri. Hal tersebut dapat kita lihat dari pandangan Kyai Sholeh yang tetap mengedepankan kebenaran yang ada dalam agama Islam sebagai agama yang dianutnya walaupun hal tersebut sama sekali tidak mengurangi penghormatannya terhadap agama lain dan tidak ada sama sekali sikap merendahkan agama lain, serta tidak menjadi ganjalan dalam menjalin toleransi beragama dalam kehidupan bermasyarakat.

Pemikiran Kyai Sholeh tentang toleransi beragama juga diimplementasikan dengan baik dalam kebijakannya yang terkait dengan pendidikan di pesantren dan di lembaga pendidikan formal milik pesantren. Sungguh hal yang luar biasa (dalam pandangan peneliti) ketika sebuah lembaga pendidikan yang berada didalam lingkungan pesantren, menerima siswa dan siswi yang berasal dari umat non-muslim. Inilah totalitas dari pengakuan adanya pluralisme agama dan persamaan hak bagi seluruh bangsa Indonesia untuk mendapatkan pendidikan yang layak, dan perlakuan yang sama dalam kehidupan bermasyarakat. Bahkan tidak tanggungtanggung penerimaaan tentang pluralitas dan upaya untuk menciptakan toleransi 
Erik Sabti Rahmawati dan M. Hatta Satria, Implementasi Toleransi Beragama ...| 105

beragama tersebut dijadikan sebagai semboyan perguruan tinggi pesantren Universitas Yudharta Pasuruan yakni "The Multicultural University”. Selain itu pesantren Darut Taqwa juga sangat aktif dalam kegiatan-kegiatan yang melibatkan

\section{DAFTAR PUSTAKA}

Abd A'la. "Merajut Kembali Persatuan Bangsa" dalam Jakarta: Kompas, 3 Agustus 2000.

Ahmad Norma Permata. Metodologi Studi Agama, Yogyakarta : Pustaka Pelajar, 2000.

Amin Abdullah (1996) Studi Agama: Normativitas dan Historisitas?, Yogyakarta: pustaka pelajar.

Andito (ed.). Atas Nama Agama; Wacana Agama Dalam Dialog Bebas Konflik. Bandung: pustaka Hidayah, 1998.

Burhani, Ahmad Najib. Islam Dinamis: menggugat peran agama membongkar doktrin yang membantu. Jakarta: Kompas Media Nusantara, 2001.

Bustomi Abu Amar "Serumpun Bambu; Jalan Menuju Kerukunan Sejati." Pasuruan: Yudharta Advertising, 2010.

Darut Taqwa, 100 Pendeta Kunjungi Ponpes Ngalah.

http://blog.daruttaqwa.or.id/2010/03/a pa-jadinya-kalau-100 pendeta.html, akses 10 Mei 2011.

Darut Taqwa,

Profil, http://blog.daruttaqwa.or.id/2010/03/p rofil.html, diakses pada tanggal 14 Oktober 2011.

Depag RI, al-Qur'an dan Terjemahannya, Bandung: J-ART, 2004.

Dhavamony, Mariasusai. Fenomenologi Agama, Terj. Kelompok Studi Driyarkara, Yogyakarta: Kanisius, 1995.

Komaruddin Hidayat dan Ahmad Gaus AF (ed.). passing Over: Melintasi Batas Agama, Jakarta: Gramedia, 1999.

Mukti Ali dkk. Agama Dalam Pergumulan Masyarakat Kontemporer. Yogyakarta: Tiara Wacana. 1998. umat lintas agama, seperti kegiatan seminar lintas agama, menerima dan melakukan kunjungan lintas agama, dan menerima umat agama lain yang live in di pesantren Darut Taqwa untuk beberapa waktu.

Pondok Pesantren Ngalah, "Kepengurusan Ponpes Ngalah" http://pondokngalah.net/pesantren/prof il/kepengurusan.html, diakses pada tanggal 20 Agustus 2011.

Pondok Pesantren Ngalah, "Kurikulum Ponpes Ngalah", http//pondokngalah.net/pesantren/profi 1/kurikulum.html, diakses pada tanggal 20 Agustus 2011.

Pondok Pesantren Ngalah, "Pendaftaran Santri”, http://pondokngalah.net/informasi/psb. html, diakses pada tanggal 20 Agustus 2011.

Pondok Pesantren Ngalah, "Sejarah Singkat Ponpes Ngalah", http://pondokngalah.net/pesantren/prof il/sejarah.html, diakses pada tanggal 20 Agustus 2011.

Pondok Pesantren Ngalah, "Visi dan Misi Ponpes Ngalah", http://pondokngalah.net/ , diakses pada tanggal 20 Agustus 2011.

Pondok Pesantren Ngalah, "Biografi Pengasuh Ponpes Ngalah", http://pondokngalah.net/pengasuh/prof il.html, akses 20 Agustus 2011.

Santri Muallimin Muallimat Ponpes Ngalah, Buku Pedoman Santri Darut-Taqwa Dalam Berbangsa dan Bernegara, Cet:1, Pasuruan: Yudharta Advertising.

Seminar Kebangsaan, Profil Penyelenggara Universitas Yudharta Pasuruan, http://seminar2010.daruttaqwa.or.id/2 010/03/profil-penyelenggarauniversitas.html, tanggal 14 Oktober 2011. 
106| de Jure, Jurnal Syariah dan Hukum, Volume 6 Nomor 1, Juni 2014, hlm. 95-106

Sunggono, Bambang. Metodologi Penelitian Hukum. Jakarta: PT Raja Grafindo Persada, 2003.

Sutrisno, Hadi. Metodologi Research. Yogyakarta: Andi Ofset, 1998.
Syamsuddin, Abdullah. Agama dan Masyarakat; Pendekatan Sosiologi Agama. Jakarta: Logos Wacana Ilmu, 1997. 